\title{
ANÁLISIS
}

\section{Rising China's Multipolar Diplomacy towards Latin America and the Caribbean: Challenges Ahead}

\author{
Aumento de la diplomacia multipolar de China hacia \\ América Latina y el Caribe: desafíos por venir
}

DOI: $10.32870 /$ mycp.v8i23.601

\begin{abstract}
Rising China has become an important promoter of changes for Latin America and the Caribbean (LAC) since the late of 1990s, and it continues on doing so particularly after the global recession in 2008. From the Chinese perspective the world is in an irreversible transition towards 'multipolarity', and LAC is not an exception. In this regard, this article makes a comprehensive analysis of the recent China's engagement with LAC and examination of China's diplomacy in LAC, studies the case of China's relationship with Venezuela, and claims that the opportunities, complexities and challenges existing in China's multipolar diplomacy towards LAC in general. The expected result is to have a representative picture of these interactions of the countries involved, and grasp how to develop better relationship between LAC and China based on the multipolar diplomacy.
\end{abstract}

Keywords: Latin America and the Caribbean, China, China's diplomacy, multipolarity, Belt and Road Initiative.

\author{
Pin $Z u o^{1}$ \\ Guillermo Antonio Esparza Pérez ${ }^{2}$
}

\section{Resumen}

China se ha convertido en actor promotor de cambios en Latinoamérica y el Caribe desde finales de los años noventa y ha asumido un papel más significativo en esta región sobre todo después de la recesión económica de 2008. Desde el punto de vista de la nación asiática, el mundo se encuentra en una transición irreversible hacia un orden multipolar y Latinoamérica es parte de este proceso. En este artículo se hace un análisis del reciente involucramiento de China con países de la región, la diplomacia que se ha implementado, además se detiene a examinar con mayor detalle la relación que existe con Venezuela; de la misma manera asevera que la presencia de China ha traído oportunidades, complejidades y retos para el área, pero también podríamos estar hablando de la transición de Latinoamérica y el Caribe hacia un mundo multipolar. El resultado esperado es tener una mejor fotografía de estas interacciones e interpretar las posibles direcciones en que los acontecimientos están guiando.

Palabras clave: Latinoamérica y el Caribe, China, diplomacia china, mundo multipolar, Iniciativa de

la Franja y la Ruta.

Artículo recibido el 07 de septiembre de 2018 y dictaminado el 05 de febrero de 2019.

1. School of International Relations and Public Affairs, Shanghai International Studies University, Shanghai 200083, China. ORCID: http://orcid.org/ 0000-0003-3140-879X. E-mail: zuopin@shisu.edu.cn

2. School of International Relations and Public Affairs, Shanghai International Studies University, Shanghai 200083, China. ORCID: http://orcid.org/ 0000-0001-5270-7903. E-mail: anguespe@hotmail.com 


\section{Introduction}

In recent decades the whole world has been eye witnessing the impressive Chinese performance in terms of economic growth and development, noticing that while China rises, all global interactions simultaneously experience fast, continuous and in many cases dramatic transformations. Some scholars described that "the rise of China as a dominant economic power in the last decade represents one of the most significant changes in the international system" (Arnson \& Davidow, 2011). However, China is causing major controversy due an existing gap and uncertain compatibility between its new proactive role in the world stage and the current international system. From different perspectives the relevance of China in the international affairs rises along its economic capacity, having as the most important implication of this phenomenon the counterbalance that Beijing represents to Washington as economic powerhouse, and its alliance with Russia, intends to rebalance the West in terms of global governance ("China is not," 2014).

For Latin America and the Caribbean (LAC), China's state capacity has already extended since the late of 1990s in a comparably fast speed and China has deeply engaged with several countries in the region, consequently bringing new opportunities and challenges. Beijing has become a promoter of changes for the Western Hemisphere, which highlights include the following: LAC has exported to China accounting for the region's total export jumped from $1 \%$ to 10\% from 2000 to 2017, and China is the third largest export market of LAC. LAC has imported from China accounting for the region's total imports jumped from $2 \%$ to $18 \%$ between 2000 and 2017, and China is the second largest of import market of LAC (Ministry of Commerce of the People's Republic of China, 2018). Sino-LAC trade volume was USD 300 billion in 2018, and LAC is still the second largest destination for Chinese overseas investment (General Administration of Customs of The People's Republic of China, 2019). China gaining a relevant presence in the region suggests a progressive decline of the Us influence, and stimulates the local economies diversification.

In short, the objective of this article is to discuss how rising China's multipolar diplomacy embrace LAC, based on a general examination of the recent Chinese engagement with LAC and the analysis of complexity, opportunities and challenges existing in China's multipolar diplomacy towards LAC. Through the case of Venezuela, this article analyzes why China has established closer 
ties with Venezuela despite of high political and economic risks besides China's multipolar diplomacy in LAC.

This article proceeds in six parts. The following section of it describes briefly the presence of the rising China in the region and how the engagement with the region has taken place and evolved. The third section makes a general description of how China's multipolar diplomacy embraces LAC. The fourth section discusses the relationships of China with Venezuela from China's multipolar diplomacy perspective. For China, Venezuela not only has a natural competitive advantage among other countries in the region but also hold a strong foreign policy and ambition to play a more important role at the regional and international level, additionally it has been so far the largest beneficiaries of the new Beijing's approach into the region, advising a particular agenda.

The fifth section explores the complexities in the relationship between China and LAC which has been grown quickly. And the conclusion highlights China as a promoter of a 'Multipolar World', building deep friendship ties with particular local countries and inciting changes in LAC, as well as the increasing LAC relevance in the changing world dynamics.

\section{Presence of the rising China in LAC}

China had few attentions on LAC in the past because of the remote distance and different culture and language between them. Strengthening economic and trade ties between China and LAC hasn't emerged till the late of 1990s. It's the result of China-driven commodity boom, which derives from the impressive economic expansion of China since its opening reforms in 1978. Trade with LAC registered an exponential growth since the early 2000's, when it increased from USD 10 billion in 2000 to USD 257 billion in 2013. The first decade of the $21^{\text {st }}$ century held a good economic start for LAC widely driven by the Asian economies, and particularly by China. Trade flows between the Asia-Pacific region and LAC reached USD 441 billion by 2011, which half corresponded to China alone. Meanwhile, the general trade share with the Asia-Pacific region grew about 20.5\% a year from 2000 to 2010. The total share of Asia in LAC's foreign trade was $21 \%$, only behind of the Us with $34 \%$ (Heine, 2015).

The 2015 China-Latin America Economic Bulletin, released by Boston University's Global Economic Governance Initiative, showed the trade balance 
between China and LAC in terms of percentage of regional GDP for the region of 2013: exports to China reached an historical record of USD 112 billion in goods, amount that equals the $2.0 \%$ of regional GDP. However, China's share of LAC goods exports by sector, reflecting how Chinese imports from the region are highly concentrated in the agriculture, forestry, fishing and extraction sectors like mining and quarrying (Ray \& Gallagher, 2015). The trade relationship patterns between China and LAC of the period can be summarized as follow: China-LAC trade relationship has increased dramatically in both ways, with China becoming its second main trading partner only after the Us; China-LAC trade has been characterized by huge imbalances particularly since 2003 with tendency to continue doing so; China-LAC trade structure reflects worrying tendencies since China's exports to LAC are relatively diversified based on manufactured exports, in contrast to LAC's exports to China which are highly concentered in few items such as iron ore, soybeans, and copper. Additionally, they hold socioeconomic and environmental inconvenient (Dussel, 2014).

Considering the reliability of the raw materials behavior in China's exports, worrying that such performance does few in contributing to the region development and limits its industrialization, the engagement between China and LAC is relativity recent, and both parts should develop a model to counter these unsustainable trade conditions as soon as possible. China-LAC economic and trade relationship must be distinguished from LAC previous experiences with other bigger economies, which have been characterized by taking advantage of the natural recourses of the region. However generally speaking these trade concerns reach all countries in the region, the situation becomes significantly different for each individual nation. It is important to observe that while most of the LAC countries are importing a diverse array of manufactured products from China, it has mainly concentrated its imports in specific raw materials, such as iron, oil, soybeans and copper, therefore its main providers are also a specific group of countries which include Brazil, Chile, Peru, Venezuela and Argentina.

The relevance of China becoming an important destination for LAC exports not only relies on the speed in which China has engaged with the region, or the existing imparities in trade, but also in the significance that China is gaining for its main supplier economies. Despites the competition that China represents for LAC in different aspects and the inconveniences of the trade performance, it is also well noted that there is a straight connection between the rise of China and a favorable economic performance for Brazil, Chile and 
Peru. China has become their first trade partner, with a better performance in trade balance, overtaking the European countries and slowly displacing us to a second place in most of the cases.

There is different from those LAC countries in the south to the ones in the north, particularly for Mexico, which is China's second trade partner and second largest economy in the region. The competition in both FDI attraction and the us market share (where China has displaced largely), and a remarkable trade deficit (in 2013 Mexico imported USD 61 billion from China and exported only USD 6 billion) between these two countries, have led to multiple misunderstandings, and regardless the 'Comprehensive Strategic Partnership' that they established in 2013, they haven't been able yet to find an appropriate path for cooperation. In November 2014, the Mexican government revoked an important high speed railway deal after few days the bidding was legitimately won by a China's state-owned enterprise and other Mexican companies, arguing 'domestic factors' (Xinhua News, 2014). It has been illustrated China's negative influence on the overall political environment in the country (Pavlićević \& Kratz, 2017). And two months later the Dragon Mart mega-mall project, which has been under construction since 2013, was also halted due to 'environmental protection' reasons (Sanchez, 2015), adding more misunderstandings to the relationship of two countries.

Another important reason why the presence of China in LAC has been particularly gaining attentions is because Chinese state banks such as the China Development Bank (CDB) and the China Export-Import Bank (CEIB) have become the greatest creditors in the region, surpassing international entities such as the World Bank (WB) and the Inter-American Development Bank (IDB) combine in their lending to the area (Gallagher \& Margaret, 2015). Chinese loans have caught attention not only because of their magnitudes, which largely surpasses that of other creditors in the region, but also because contrary to other countries or international institutions China don't impose some policy conditions in order to grant them, they are less strict with environmental guidelines, and detailed figures regarding their loan activities are not regularly published (Gallagher, Irwin, \& Koleski, 2012). This lending method has not been well perceived by some scholars and media in the West, but also it is well noted that it has given an advantage to Chinese approach in the region, as noted that "China also holds an advantage over the US, it doesn't want to intervene in politics or tell leaders how to govern. That's a 
stark contrast from the US, which has a long history of intervening in Latin American politics" (Gillespie, 2016).

However, one more factor which has been largely criticized is that normally deals require working with Chinese contractors, give preference to Chinese business companies and Chinese workers, limiting the employment of local human resources, while from other perspective it is also well observed that they are directed to target sectors such as infrastructure, energy, mining, telecommunications, housing and other important areas for development, and in a general scope their terms seem to be more favorable for its receptors. Though China's lending predominant characteristic, which raises questions as well, has been that commonly loans are based in exchange of raw materials, such as oil usually, contrary to what many people think the deals are actually functional for some countries in LAC, since they observed that China gets payments back based on current oil prices, and they could result more practical for the nations involved (Gallagher et al., 2012).

Nevertheless, current situation holds an unusual drop down in oil and other commodity prices, adding new concerns about how the deals are being managed since the situation is leading to serious crises in China's main credit recipients. The method being used by China to award credits to LAC has been commonly named as 'loans for oil', paying special attention in China's interest for such a substance, however for other observers these loans could also receive other names such as 'loans for development'. Based on these spectators' observations there is a genuine and favorable Chinese behavior in contributing to the recipient country development (Castillo, 2009).

\section{China's multipolar diplomacy in LAC}

China's diplomacy among other essential pronouncements embraces three important concepts: 1) 'Peaceful development'. 2) 'Multipolar World'. 3) 'South-South Cooperation'. The conception of 'Multipolar World' started gaining prominence around the world since the early 1990s. Former Chinese President Jiang Zemin officially included the concept as 'duoji shijie' into the Chinese foreign policy in 1992, during the $14^{\text {th }}$ Congress of the Communist Party of China, under the vision that a peaceful world is only possible through 'multipolarity'. Chinese president Xi Jinping addressed the term of 'Multipolar World' at $70^{\text {th }}$ UN General Assembly on September 28, 2015. Currently China and 'BRICS nations' could be considered as the earliest coordinated expression 
in building a 'Multipolar World' since the post-Cold War era, the aims of this partnership includes the 'South-South Cooperation' ideology and has been gaining considerable attentions since its founding in 2009.

China's multipolar diplomacy arrived in LAC during the late of 1990s, and since then China's influence has been exponentially increasing, China has built important cooperation agreements with countries such as Brazil, Venezuela, Argentina, Peru, Chile, Cuba, Mexico, Costa Rica, and Ecuador. In November 2008, China gave a chief turn into formality in its relationship with LAC by issuing a policy paper towards the region. Action that for many has been a major proof of China's growing influence in the international system, since the region is closely regarded within the us sphere of influence and after the Cold War no other country before has attempted to approach the area in a similar way (Castillo, 2009). The policy paper of 2008 is a conduct in which the Chinese Government expresses its interest in deepen relationships with LAC, it intends to clarify Chinese expectations on doing so and provides an initial guideline for upcoming cooperation.

In the policy paper of 2008, China states that the world is experiencing important transformations and adjustments, remarks peace and development has trend of modern times and an irreversible transition towards multipolarity (Ministry of Foreign Affairs of the People's Republic of China, 2008). The goals of China's policy in LAC are the first time described clearly as follows: promoting mutual respect and mutual trust and expand common ground (based on the five principles of peaceful coexistence); deepening cooperation and achieve win-win results; drawing on each other's strengths to boost common progress and intensify exchanges; the political basis of one China principle for the establishment and development of relations between China and LAC and regional organizations.

In July 2014 the 'China-LAC comprehensive cooperative partnership of equality, mutual benefit and common development' and the 'China-CELAC forum' were established, taking another step forward in the China's engagement with LAC, it proves the important role of LAC in China's diplomatic pattern (Zhu, 2016). Like the 'China-CELAC forum', which held its First Ministerial Meeting in Beijing in January 2015, could be understood not only as other Chinese intent to advance its engagement with countries in the Western Hemisphere but also it is the biggest positive expression made by LAC as a whole in response to Chinese multipolar diplomacy, and it expresses the region willingness to keep developing bilateral and overall cooperation. 
China has been gradually expanding its influence in LAC and proportionally has been gaining recognition, and much has been done due to its multipolar diplomacy towards the region. Beijing has also pursued the region by recognizing its richness and potential, and embraces it as a friend, working together to create development and peace in the world. This has been endorsed in China's white paper policy on LAC issued in 2008, and stated by Chinese president Xi Jinping in his visit to Mexico on June 2013,

Once again, visiting Latin America, a vibrant and promising continent, I am all the more convinced that with its rich natural endowments, this continent is embracing another golden period of development. We believe that a more prosperous LAC region will benefit both the rest of the world and China (Xi, 2014).

These words beyond given recognition, address LAC as an essential part of the Chinese vision and quest for Global Order again.

China's multipolar diplomacy in LAC is diverse and involves both economic and political perspectives; it doesn't mean the diplomacy without focus. Although when China has expressed its intention to build fruitful relationships with LAC as a whole, it has identified key countries within the region, and in a mutual agreement has denominated them 'Strategic Partners', some countries such as Brazil (1993/2004), Argentina (2003), Mexico (2003), Venezuela (2001), Peru (2008), Chile (2012), Costa Rica (2015), and Ecuador (2015). Some of these partnerships have been upgraded to 'Comprehensive Strategic Partnership' such as the case of Brazil (2012), Mexico (2013), Peru (2013), Argentina (2014), Venezuela (2014) and Chile (2016). 'Strategic Partnership' is understood not only as a good momentum in bilateral ties but also suggests recognition of both parties for common objectives. At the same time 'Comprehensive Strategic Partnership' advises deeper commitment of the parties involved to increase and widen their efforts in cooperation (Zhao \& Jun, 2014). China's growing partnerships with LAC are also interpreted as progress of China's influence in the region. Another example is the case of Cuba, which doesn't hold any of these labels but keeps one of the closest relationships with China in the region, greatly because they both are socialist countries.

Furthermore, the multipolar diplomacy means that China hopes to testify the relevance within the countries of the whole region. It has been represented more and more clear since July 2014. Ms. Wang Ke, Chinese former ambassador to Barbados, in the article "A New Chapter in China-LAC 
Friendship and Cooperation" described 'the new cooperation framework' that Chinese President Xi Jinping proposed to build together with the region during his visit to Brazil in July 2014. During this visit, the 'China-LAC comprehensive cooperative partnership of equality, mutual benefit and common development' and the 'China-CELAC forum' were established (Wang, 2014). Chinese President Xi Jinping also proposed to jointly build a new ' $1+3+6$ ' cooperation framework: ' 1 ' means 'one plan', referring to the establishment of the China-Latin American Countries and Caribbean States Cooperation Plan (2015-2019); ' 3 ' means 'three engines', referring to promoting the comprehensive development of China-LAC practical cooperation with trade, investment and financial cooperation as the impetus; ' 6 ' means 'six fields', referring to boosting China-LAC cooperation in energy and resources, infrastructure construction, agriculture, manufacturing, scientific and technological innovation, and information technologies as priorities (Xi, 2014).

China released its second policy paper on LAC on November 24, 2016. Compared with the first one issued in 2008, the new policy paper added more new contents in China's multipolar diplomacy to LAC (Ministry of Foreign Affairs of People's Republic of China, 2016), including:

1. A new definition of position of China-LAC relationship. China hopes to build "a community of shared future" with LAC and "a model of seeking to common development, with the aim of sharing responsibility and facing common challenges in developing countries in the new era".

2. New cooperation measures to achieving win-win situation. First, China will support and promote the combination of state-owned, private, large, small and medium-sized enterprises between China and LAC. Second, China will change its aid model that will turn from 'hard aid' in the past to the 'soft aid' like enhancing the developing capacity of LAC, and Chinese enterprises will also take more social responsibility for this region. Third, the new policy paper emphasizes the environment protection and sustainable development of LAC. China has already held a roundtable dialogue on environmental and development policies with LAC in Beijing in 2017. It is an unprecedented level of relationship between China and LAC (Guo, 2017).

3. Specifically listing out the objective of cultural cooperation. China has paid more attention to the cultural exchange between China and LAC than before. 
4. Promoting the comprehensive cooperation with LAC as the whole. China will take a collective cooperation strategy for all of countries of LAC.

5. A new plan of trilateral cooperation. China will welcome a trilateral development cooperation plan, which includes countries outside the region under the premise of a cooperation agreement framework.

Before 2016, some scholars had queried the importance of LAC in China's diplomacy after the Belt and Road Initiative was proposed in 2013 by Chinese President Xi Jinping, because the earliest route map of the Belt and Road Initiative had not the south line for LAC. Such as Chinese scholar Xue Li said China should not overestimate the strategic significance of LAC. For LAC, the Belt and Road Initiative means "though China has money, it will cost cautious not wayward" (Xue, 2014). Nathan Bauchap-Mustafaga from The Jamestown Foundation also commented: "China has satisfied with the current pattern of the relationship with LAC, will not seek to put the region in a grand strategy" (Bauchap-Mustafaga, 2015).

In the new policy paper, China has also expressed its multipolar thoughts for LAC in the Belt and Road Initiative since the late of 2016. China has emphasized that it is an open and inclusive development platform. Every country is an equal participant, contributor and beneficiary under this platform. And it welcomes the active participation from LAC; so far, nearly 20 officials of ministerial-level and regional organizations of LAC. Presidents of Chile and Argentina also participated the Belt and Road Cooperation Forum which held in May 2017. Just three days ahead of the Second Ministerial Meeting of the China-CELAC Forum which was held in Santiago, Chile, from January 19 to 22, 2018, Chinese Foreign Minister Wang Yi said that China hopes to make the China-Latin American cooperation a new model of SouthSouth cooperation. Both China and the LAC need to strengthen the top-level design and deepen policy coordination, and then work out a roadmap and guidelines for the joint construction of the Belt and Road (Xinhua News, 2018). The Second Ministerial Meeting adopted three outcome documents, including the Declaration of Santiago, the Joint Action Plan of China-LAC Cooperation (Priority Areas) (2019-2021) and the Special Statement on the Belt and Road Initiative. These documents mainly reflected a clear signal of the two sides to deepen cooperation and seek common development in the new stage. After China and Panama signed the first cooperation MOU of the Belt and Road Initiative in November 2017, China has signed MOUs of the Belt and 
Road Initiative with more LAC countries within 2018, including Uruguay, Costa Rica, Ecuador, Bolivia, Venezuela, Chile, etc.

\section{Sino-Venezuela: the energy cooperation and strategic political partnership}

The Sino-Venezuela relationship mainly lays in four main arguments: 1) China secures access for oil supply, which could lead an important contribution to solve current and future energy needs to continue its development. 2) Venezuela reaches certain level of economic independence from the US, helping Venezuelan economic diversification and favoring its anti-American policy. 3) Venezuela through its cooperation with China is creating a window and giving access to other countries to be more active in the Western Hemisphere. 4) The uncertainty of the US reactions towards these interactions. So far the Us has found itself in the need to strengthen its presence into the region, while continuing its soar policy by demonizing the Venezuelan regime. These circumstances could lead to added misunderstandings with China and other countries.

The relationship between China and Venezuela is considered one of the most significant parts of China's multipolar diplomacy in LAC. It has been reflected by the creation of the Chinese-Venezuelan joint investment fund, which up to 2015 has awarded Venezuela with about USD 65 billion dollars in loans from China since it was established in 2007. This amount represents more than the half of the total loans that China has given to the whole region, which reached about USD 125 billion during the same period. As mentioned before China has become the largest creditor for LAC, surpassing international institutions such as WB and IADB combined (Gallagher \& Margaret, 2015). In the case of Venezuela these deals have been mostly based in exchanges for crude oil shipments. In 2015 Venezuela occupied the 7th place as China's biggest crude oil supplier (Smith, 2015) exporting about 600,000 barrels per day, estimating that approximately half of them are destined for loan repayments (Kaiman, 2015).

But the current significance has become more and more controversial with the increasing domestic instability of Venezuela in recent years. Since the end of 2014, Venezuela's economic situation has been deteriorated and the social unrest has been intensified because of the sustained decline in international oil prices. According to the report of the Institute of World Economics and 
Politics of the Chinese Academy of Social Sciences in 2015, Venezuela was the most dangerous investment destination for China, its investment environment has been thought worse than Iraq and Sudan(The South China Morning Post, 2016). In September 2015, the Economist reported that China has lent Venezuela USD 56.3 billion, of which USD 20 billion has not been repaid till now ("Why China is lending," 2015).

Though a top recipient of $\mathrm{CDB}$ and CEIB loans in the past, Venezuela received no finance from policy banks in 2017, after a loan of only $\$ 2.2$ billion in 2016, aimed at improving the country's oil production capacity. The year of 2017 was the lowest on record for Chinese state-to-state finance in LAC since 2012, with only approximately USD 9 billion in loans from CDB and CEIB to LAC governments and state-owned enterprises (Inter-American Dialogue, 2018). However, China has repeatedly declared that Venezuela was one of important countries of LAC, and China hoped that Venezuela could deal with their internal affairs, maintain national stability and economic and social development, and solve debt problems with the support from China. China has also denied some rumor which China may stop offering loans to Venezuela due to concerns that the country won't be able to repay its debt. Hua Chunying, the spokesperson of Chinese Ministry of Foreign Affairs said that the practical cooperation between China-Venezuela following principles of equality, mutual benefit, common development and commercial rules, is lawful and beneficial, and China would continue its across-the-board exchange and cooperation with Venezuela while upholding the above principles (Ministry of Foreign Affairs of the People's Republic of China, 2019).

The current role that Venezuela plays in LAC obeys primarily to two special factors: its reserves in crude oil and the controversy of its leadership. This kind of role possesses the largest proven reserves of crude oil not only in the region but in world, estimated in 302.25 billion barrels in 2016 (OPEC, 2016), making of it a strategic geopolitical factor on the region. However, it is also seen as the controversial leadership because of Venezuelan President Hugo Chavez (1954-2013) who took office in 1999, and the continuation of his legacy by current President Nicolas Maduro since 2013. Chavez foreign policy sustained, led and strengthened the anti-Us wave that has always been present in LAC, since the countries obtained their independency about 200 years ago, proclaiming himself against the Us and following socialist ideals, which he commonly described as Bolivarian principles. Additionally, Chavez had been a proactive regional leader by pursuing the integration and 
collaboration of LAC, he was a key founder of organizations such as Alianza Bolivariana para los Pueblos de Nuestra América (ALBA), Unión de Naciones Suramericanas (Unasur), CELAC, and was an active member of Southern Common Market (Mercosur).

The particular case of CELAC which was established in Venezuela in 2011 has attracted attentions because it is the first international body that involves all 33 LAC countries in efforts to independently coordinate regional interests, leaving on the side the influence of us by being an alternative organization to the Organization of the American States (OAS). To Carlos Caicedo, head of Latin America Forecasting at Exclusive Analysis, "CELAC reflects in part Latin America's growing awareness of its global importance" (Tavener, 2011). Two polar opposites towards the Us polices in LAC have been described since then, in one side there is Mexico which seems to be friendly to the US, and in the other side is Venezuela being the Us bête noir. The rest of LAC somehow overlaps with this two postures or develop their own combinations of pro and anti-imperialist policies (Petras, 2014).

The relationship between China and Venezuela also came to a closer path during Chavez's mandate, since early Venezuela demonstrated its continuous interest for deepen tides with Beijing. Initially in a unilateral way President Chavez recognized China's relations as 'strategic alliance' and eventually elevated them as almost a national priority (Fernández \& Hogenboom, 2012). Venezuela's interest is to reduce its dependency from the US markets for oil; ironically, Venezuela is the $4^{\text {th }}$ largest crude oil provider for the US, with an average of 733,000 of barrels a day in 2014 (U. S. Energy Information Administration, 2015). Furthermore, Venezuela has proclaimed its desire and need for a Multipolar World, where it could play a leadership position backed by its vast oil reserves. While Venezuelan strategy for commercial diversification is not limited to China, the economic and political cooperation with Beijing was early identified as crucial to reach Venezuela's national interest.

From the Chinese perspective, Venezuela has been recognized as 'strategic partner' since 2001, that same year the China-Venezuela High-Level Mixed Joint Committee was established, allowing a better coordination and cooperation in relevant departments of both countries, and since then relationship has been improving widely. Trade went from less than USD 500 million in 1999 to about USD 7.15 billion in 2009 (Suggett, 2010), under the two Presidents Chavez and Maduro, over 400 cooperation agreements have been signed, encompassing a wide array of sectors, including energy, telecommunications, 
education, health, trade, housing, agriculture, manufacturing, infrastructure, sports, research, and cultural exchange (Koerner, 2015). Venezuela has become fast and largely China's number one loans recipient in LAC, about USD 65 billion from 2007 to 2015, most of this credits act upon the China-Venezuela Joint Fund, in which Chinese companies can be repaid through Venezuelan agencies using the Joint Fund's financial resources (Dussel \& Ariel, 2015).

The interpretation given to Chinese loans in Venezuela includes a wide array of understandings. From a negative perspective, there is a lack of transparency from the Chinese enterprises, the commitments made have unclear conditions, and reports are imprecise. Moreover, Venezuela's resources and production have been seriously compromised and the investment is not solving the country's structural problems but only maintaining a government with a determinate rhetoric (León, 2015). Other criticisms include those main Chinese borrowers in Venezuela that could not easily obtain credits from international financial institutions. Contrarily to these financial institutions and some Western countries, China does not impose political or structural conditions for lending, and pays insufficient attention to environmental issues. Additionally, concerns rise since the instability of the oil prices, doubting economic advantages for LAC.

From a positive perspective, it is well accepted that Chinese loans usually target infrastructure and industrial projects, making real contributions to the development of recipient countries, by closing the infrastructure gaps existing in LAC (Gallegar \& Marchán, 2013). Technology transfer is one of the ways in which the Sino-Latin American relationships are developing, Chinese companies are teaching Venezuelans how to do oil drilling, while before there was a dependency in other countries' technicians and companies such as the Us Chevron.

Some other scholars stress the idea that it is difficult to make a conclusion with confidence about the true motivations behind the peculiar growing relationship between China-Venezuela, arguing that despite a genuine interest for energy based economic cooperation, China is also interested in the survival of Venezuela as a populist regime, as long as it doesn't conflict its stable relationship with the United States. The uniqueness in approaches made by the China toward Venezuela, are a clear reflection of China's expanding global interest, and the efforts made by the Latin American leaders challenging the US dominance create spaces in which China can operate and do business and build relationships in the Americas. Although Chinese diplomacy actively seeks to 
avoid actions that appear to confront the US, the anti-Us Bolivarian project of the Chávez regime nonetheless benefits the PRC strategically (Ellis, 2010).

The support given by China to the Venezuelan regime hasn't been well perceived from several scholars and media, since in September 2015 China provided another USD 5 billion loan to the President Maduro's administration which was described as 'beleaguered'. Professor Evan Ellis was quoted as follows: Whatever Beijing's motivations, the practical effect of said loans has "enabled countries such as Venezuela to continue as de facto sanctuaries for criminal and insurgent groups, and also, as points of entry into the region for Russia, Iran and other actors with potentially hostile intentions toward the United States" (Cárdenas, 2015).

After current President Maduro took office in 2013, the 'Bolivarian process' also known as 'Chavismo' is facing its worst historical crises, based on a lack of leadership, a series of unfavorable changes at the international level that have deepened the domestic economic crisis, and the loss of Chavez as it's most important political figure and ideological referent (Biardeau, 2015). President Maduro has pointed the Us intervention in Venezuela's national affairs by orchestrating anti-government demonstrations in the country (Tegel, 2014) and creating an economic war, which has been intensified when the us defined the Latin American country as a threat for us national security. Furthermore, the legitimacy of Maduro's administration has been put into risk since the opposition won majority of seats in the National Assembly during last Venezuelan elections in December 2015. At the closing of the summit of the Americas on April 14 in 2018, the United States, the Panama and 14 members of the Lima Group signed a joint statement for the first time and declared that they would not recognize the result of upcoming election of Venezuela. Although Mr. Maduro won re-election in May of 2018, the opposition leader Juan Guaidó, a 35-year-old former engineer, declared himself the nation's 'interim president' on January 23, 2019. But two Presidents is not worthy of celebration, it represents the beginning of a new crisis for this poor but oil-rich South American nation (Shixue, 2019).

Besides the great challenge faced by Maduro is to gain back the trust of the Venezuelan people, and that would only be archived by tangible results in improving its economy, in circumstances where time is limited and there are unstable financial conditions on a global scale. He will also worry about the immediate emergency that the US and other countries could intervene Venezuela's internal affairs. For current Venezuela's crisis, Hua Chunying, the 
spokesperson of Chinese Ministry of Foreign Affairs said on February 6, 2019, China believes that Venezuela's affairs should be resolved by the Venezuelan people under the framework of its Constitution and laws and through peaceful dialogue and political means. This is the only way towards enduring peace in the country. China supports the efforts by the international community to this end and hopes that all sides will continue to play a constructive role in the peaceful resolution of the Venezuela issue (Ministry of Foreign Affairs of the People's Republic of China, 2019).

Although the instability being face by Venezuela has raised some questions about the way China has engaged with it, a successful Venezuela would be translated in a successful cooperation with China, and therefore seen as an example for the rest of the LAC and the World. For China, cooperation with Venezuela should be understood as China's willingness to develop win-win relationship with the region as a whole, rather than a country in particular. Furthermore, it could be also interpreted that despite the struggling process China is ensuring access to the Venezuelan oil and LAC market, while the geopolitical factor pushed Beijing to support the Venezuela unconditionally.

\section{Complexities of the rise of China's multipolar diplomacy in LAC}

In a general scope and the case of Venezuela, we can have an idea of the complexity of the relationship between China and LAC. Since 2014, there has been increasing concerns due a constant and exaggerated drop down in the commodities prices, especially in oil, which is currently being sold for around USD 63/BBL (Trading economics, 2018), these circumstances have caused serious economic problems especially among LAC's largest economies. Meanwhile, China is facing a slowdown in its economy, being adjusted into what has been called 'a new normal' expecting an annual GDP grow from $7.3 \%$ to $6.9 \%$ since 2014-2017, and Chinese economy growing of 2019 could be in this range, instead of its previous common average of $10 \%$ (Focus Economics, 2019). Although for an economy like the Chinese this percentage still is considerably a relative high rate, fears are that the slowdown may affect specific sectors in which the LAC countries are involved. However even when China has started its journey in shifting its economic model, it is still likely that China will continue dominating the manufacturing sector in the long term, representing limitations for other developing countries ("Made in China," 2015). 
While the complexities for China and LAC in deepening relationships are multiple and diverse, here are three factors which should be considered the most relevant. Firstly, for LAC particularly in the strategic and policy sphere, where LAC institutions are ill-prepared: contrary to China long-term development strategy with hundreds of instruments to promote an upgrading process, most of LAC countries like Mexico show little potential to compete with China today and in the future (Dussel, 2014). Fragile economy and political structures have made most of the LAC countries weak and vulnerable, not only limiting LAC from competing with China, but also representing a possible obstacle when searching to deepen ties, especially for long term projects. The challenge for LAC then is to evolve and be able to catch up with the new circumstances in order to make the most out of them.

Secondly, Chinese activities in LAC, especially large scale projects that involve the construction and the extraction sectors, have been seriously signaled because of their negative implications toward environment and society, creating controversy in local communities and reaching international levels (Chang, 2015). One of these cases is the Nicaraguan Canal, which is led by the Hong Kong company (HKMD Group), and at the same time this enterprise has been identified as not related to any Chinese governmental institutions, furthermore HKMD group has claimed that according with the British consultancy 'ERM' the positive benefits of the project will exceed the negative environmental and social impacts (Xinhua News, 2015). In some sense, this project is creating major concern in local and international community and in general a bad image towards China; as the Chinese Ministry of Commerce warned before: there is a potential risk of becoming involved in local political and territorial disputes in the Central American country (Wei, 2013). A bad interpretation of events could provoke serious misunderstanding in LAC societies and affect other Chinese projects. On the other hand, it is also true that a 'media war' is taking place to discredit the rise of China in the region, as well as concerns emerged including the existence of geopolitical games in these actions, since many observers believe that the Nicaragua canal goes beyond economic needs, and it is a Chinese tool to challenge us dominance in region (Russia Today, 2014).

Thirdly, due to the special relationship between LAC with the Us historically, the traditional geopolitical factor is the most representative when interpreting China's rise to LAC. In the book known in Spanish as China irrumpe en Latinoamerica: Dragon o panda? introduces a metaphor showcasing 
two faces of China, one is a Friendly Panda and the other is a Hungry Dragon. It is up to LAC to choose which physiognomy China would take, and stresses that LAC should not commit the same mistakes from the past with the US and Europe (Jalife-Rahme, 2012). The us need for an 'intelligent, aggressive, integrated policy' in order to pursuit better LAC and to have better gains in all sides before China ended up overshadowing the Us influence in the region (Fumento, 2014).

The Us has already been adjusting its agenda in LAC since President Barack Obama took office in 2008, especially in the second term and much has been done due to the China's rise in the region and the Russian approach, some examples could be found in the following events: 1 ) the US-Colombia Defense Cooperation Agreement established in 2009, allows the us personnel to be stationed at seven military bases in the South American nation (CNN, 2009). 2) The Us-Mexico High Level Economic Dialogue established in 2013 modifying the regular agenda between the two neighbor countries which basically used to be limited to migration and security issues (CFR, 2015). 3) Unites States policy shift towards Cuba, by the end of 2014 President Obama addressed a 'new chapter' in US relations with Cuba, publicizing intentions to normalize diplomatic and economic ties (BBC, 2014). In March 2016, President Obama paid a historic visit to Cuba. 4) President Obama declares Venezuela a threat to U. S. national security in March 2015.

However, the US foreign policy in LAC has been new changes since President Trump took office in 2017, like restarting negotiation of NAFTA, promising to build a wall along the border with Mexico. And the relationship between the US with Cuba is becoming unclear, President Trump has suggested the suspension of the normalization process after criticizing aspects of the Cuban Thaw unless he can negotiate 'a good agreement'. During the $8^{\text {th }}$ Summit of the Americas was held in Lima, Peru on April 14 2018, Vice President of the United States Mike Pence who was filling in for President Trump blamed Cuba for exporting its "failed ideology across a wider region" (Wyss, 2018). On November 1 2018, National Security Adviser John Bolton gave a speech that called for minimizing diplomatic contact with Cuba and ramping up sanctions on Venezuela and Nicaragua, denouncing the three socialist countries the 'Troika of Tyranny'. Bolton's speech is among the clearest statements of the administration's views on Latin America that we've seen so far, and Bolton depicted it almost as a struggle of good versus evil (Swan \& Lawler, 
2018). Due to Trump's populism and 'America First' approach to trade, the Us foreign policy in LAC would be tougher than any time undoubtedly.

Generally, the emergence of China is essential to bring new opportunities to LAC, at the same time the suggested competition with the US could also have been transformed into opportunities. Unfortunately, the challenges and the risks rely on a framework where competition is not always loyal and fair. However, the circumstances should be understood as time of changes and it seems that the transition to a multipolar diplomacy might take some painful steps. LAC needs to embrace the new opportunities and behave according to the new circumstances, while China and LAC should be working more not only at the official level but also within their societies, in people to people relations to learn to perceive each other not only as an option but as friends. While for LAC the challenge is to grow up and become internally strong in order to better embrace the external changes, for China it is to prove its capacity as a global leader, taking responsible actions and behave. As a Chinese proverb quoted by Chinese President Xi Jinping: "just as distance tests a horse's strength, time will show a person's sincerity" (Xi, 2014), in a world that the relation between China and LAC has been characterized by being exclusive, expectations on the Chinese leadership are high.

\section{Conclusions}

The year of 2008 is marked as a shift for Sino-LAC relationships. In this year, China as a rising power issued the first policy paper on the region. After eight years, China published its second policy paper towards LAC in November 2016. The recognition and invitation made by Beijing to the region are significant since LAC has never been approached in a similar way before. After the Monroe Doctrine and the Washington Consensus, LAC fell in an isolated and lack of opportunities road for survival, with hopeless dreams to become part of the so called developed world. Now for the first time, the region receives a friendlier, free and equal offer to continue its search for progress and it was made by no other country but China.

The arrival of the new version of China to LAC is a good reference to understand the magnitude of the changes that are taking place in the international system. For LAC, this new approach brings multiple opportunities for all counties in general, but also takes challenges into new dimensions. Therefore, China should not necessarily be understood as a solution or a threat to the 
region but as a promoter of deep and historical changes, it is then responsible for the LAC to embrace them properly. The creations of 'Unasur' in 2008 and 'CELAC' in 2010 are the strongest expressions of an autonomous LAC seeking for a common agenda and to become a bigger player in global governance. The case of 'CELAC' in particular is notable because in one way it reflects LAC aims to reduce the Us influence on the region, being an alternative body of OAS, while on the other hand welcomes the Chinese presence by creating a strategic partnership with it and establishing the 'China-CELAC Forum', revealing not only how crucial in importance $C$ hina has become for the region but also how LAC is taking its first step to being part of Multipolar world.

While China's presence in LAC is relevant for the region as a whole, it has been predominantly gainful for countries such as Brazil, Mexico, Chile, Peru, Argentina, and Venezuela among others, but it also holds a different meaning beyond economic benefits for countries such as Venezuela, Brazil, and Cuba in particular. In the case of Venezuela, Beijing's support has been essential to continue their national agenda, which includes reduction of the Us influence on the region, and aims to play a greater role at regional and international level. The readjustment of the international system is being sensed in different ways in each part of the world, important LAC economies such as Mexico, Brazil, Venezuela, Argentina, among others are facing a period where their societies no longer feel identified with their political class; corruption, economic crisis, inequality, extreme dependency to the Western financial system, make these countries particularly weak, impoverish them, and make them easy to manipulate. The situation for LAC then, far from being free to create its own strategy to reach a stable path to development, however this stage also could be understood as a painful process.

China's multipolar diplomacy in the region should be extremely cautious, avoid misunderstandings and underestimating challenges; should give the necessary priority to the region and know the sensitivity of societies and governments towards imperialistic behaviors; should be aware of the importance of media and get to know each country better, cultures, societies and their desires, which would summarize in need of justice, equality and opportunities. For LAC, societies and governments should understand China better and the opportunities that it brings, while also proving its capability to evolve and face the challenges that come along with multiple opportunities. ng? 


\section{References}

Arnson, C. J., \& Davidow, J. (2011, July). China, Latin America, and the United States: The New Triangle. Retrieved from https://www.wilsoncenter.org/ publication/china-latin-america-and-the-united-states-the-new-triangle BBC. (2014, December 17). Obama hails 'new chapter' in US-Cuba ties. Retrieved from http://www.bbc.com/news/world-us-canada-30516740

Beauchamp-Mustafaga, N. (2015).The new silk road and latin America: will they ever meet? China Brief a journal of analysis and information, The Jamestown Foundation, 15(5), pp 1-18. Retrived from https://jamestown. org/wp-content/uploads/2015/03/China_Brief_Vol_15_Issue_5_1. pdf?x87069

Biardeau, J. (2015, October 26). Chavismo Must Face the Crisis and Correct its Course. Venezuelanalysis. Retrieved from http://venezuelanalysis.com/ analysis/11616

Cárdenas, J. R. (2015). Why is China Brankrolling Venezuela?. Foreign Policy. Retrieved from http://foreignpolicy.com/2015/09/04/why-is-chinabankrolling-venezuela/

Castillo, A. (2009, June 18). China in LatinAmerica. The Diplomat. Retrieved from http://thediplomat.com/2009/06/china-in-latin-america/

CNN. (2009, October 30). Colombia, U.S. sign deal on use of bases. Retrieved from http://edition.cnn.com/2009/WORLD/americas/10/30/ us.colombia.bases/index.html

Council on Foreign Affairs. (2015). Documents of U.S.-Mexico High Level Economic Dialogue. Retrieved from http://www.cfr.org/competitiveness/ documents-us-mexico-high-level-economicdialogue/p35927

Chang, L. (2015). Chinese firm to start Nicaragua canal project by late 2016. China Daily. Retrieved from http://www.chinadaily.com.cn/business/2015-11/06/content_22388919.htm

China is not a threat, but a challenge. (2014). The Guardian. Retrived from http://www.theguardian.com/commentisfree/2014/may/25/observereditorial-china-challenge-not-threat

Dussel, P.E., \& Armony, A. C., (Coords.), (2015). Beyond raw materials: who are the Actors in the Latin America and Caribbean-China Relationship? Buenos Aires: Friedrich-Ebert-Stiftung. Retrieved from http://www.redalc-china. org/v21/images/docs/Dussel_Armony_BeyondRawMaterials.pdf 
Dussel, P. E. (2014). New Forms of International Cooperation: the case of Latin America and the Caribbean and China. China Studies Quarterly 4. Shanghai: Shanghai People's Press.

Ellis, R. E. (2010, August 18). Venezuela's Relationship with China: Implications for the Chávez Regime and the Region. University of Miami, center for hemispheric policy. Retrieved from https://wikileaks.org/gifiles/ attach/15/15968_Ellis_Venezuelas_Relationship_w_China.pdf

Fernández, A., \& Hogenboom, B. (Eds.), (2012). Latin America Facing China: South-South relations beyond the Washington Consensus. New York: Berghahn Books.

Focous Economics. (2019, February 19).Chinese Economic Outlook. Retrieved from https://www.focus- economics.com/countries/china

Fumento, M. (2014). As The U.S. Sleeps, China Conquers Latin America. Forbes. Retrieved from http://www.forbes.com/sites/realspin/2014/10/15/ as-the-u-s-sleeps-china-conquers-latin-america/\#1da15ce8162d

Gallagher, K. P., Irwin. A., Koleski. K. (2012). The new banks in town: Chinese Finance in Latin America. The Dialogue. Retrieved from https://www. thedialogue.org/resources/the-new-banks-in-town-chinese-finance-inlatin-america/

Gallegar, K., \& Marchán, E. (2013). China is the new bank in Latin America is it a better deal?. Triple Crisis. Retrieved from http://triplecrisis.com / china-is-the-new-bank-in-latin-america-is-it-a-better-deal/

Gallagher, K. P., \& Myers, M. (2015). China-Latin America Finance Database. The Dialogue. Retrieved from http://www.thedialogue.org/map_list/

General Administration of Customs of the People's Republic of China. (2019). The trade volume between China and Latin America exceeded us $\$ 300$ billion, with outstanding performance in agricultural and sideline products. Retrieved from http://chinawto.mofcom.gov.cn/ article/e/r/201902/20190202832613.shtml

Gillespie, P. (2016). Latin America: China's power play right under the U.S. CNN Money. Retrieved from http://money.cnn.com/2016/02/11/news/ economy/china-latin-america-billions-of-dollars-loans-investments/ index.html

Guo, C.H. (2017). China's policies and practices in LAC since the 18th CPC national congress. Latin American studies, 39(2),1-16.

Heine, J. (2015). The next step in China-LAC. CRIES. Retrieved from http:// www.cries.org/?p=2455 
International Trade Administration. (2015). Documents of U.S.-Mexico High Level Economic Dialogue. Retrieved from https://www.trade.gov/hled/ hled-progress-report.asp

Jalife-Rahme, A. (2012). China irrumpe en Latinoamerica: dragon o panda?. Mexico City: Orfila.

Kaiman, J. (2015). China agrees to invest $\$ 20$ bn in Venezuela to help offset effects of oil price slump. The Guardian. Retrieved from http://www. theguardian.com/world/2015/jan/08/china-venezuela-20bn-loansfinancing-nicolas-maduro-beijing

Koerner, L. (2015). Venezuela Strengthens Ties with China, Iran, and the Caribbean. Venezuelanalysis.com. Retrieved from http://venezuelanalysis. com/news/11429

León, A. (Producer) (2015). Role of Latin A merica in the Chines strategy to satisfy its enormous need for hydrocarbons. [Audio in Podcast]. Retrieved from http://dusselpeters.com/CECHIMEX/260815leonhidrocarburos.mp4

Made in China? (2015). The Economist. Retrived from http://www.economist. com/news/leaders/21646204-asias-dominance-manufacturing-willendure-will-make-development-harder-others-made

Ministry of Foreign Affairs of the People's Republic of China. (February 14, 2019). Foreign Ministry Spokesperson Hua Chunying's Regular Press Conference on February 14, 2019. Retrieved from https://www.fmprc.gov.cn/ mfa_eng/xwfw_665399/s2510_665401/2511_665403/t1638000.shtml

Ministry of Foreign Affairs of the People's Republic of China. (February 08, 2019). Foreign Ministry Spokesperson Hua Chunying's Remarks on the Inaugural Conference of the International Contact Group on Venezuela. Retrieved from https://www.fmprc.gov.cn/mfa_eng/xwfw_665399/ s2510_665401/2535_665405/t1636418.shtml

Ministry of Commerce of the People's Republic of China. (2018). Economicy and Trade Cooperation between China with LAC Increased steadily in 2017. Retrieved from http://www.mofcom.gov.cn/article/i/ jyjl/1/201802/20180202710448.shtml

Ministry of Foreign Affairs. (2018). China-LAC cooperation to level up along 'Belt and Road': FM. Retrived from http://www.chinacelacforum.org/eng/ zyxw_1/t1528019.htm

Ministry of Foreign Affairs of the People's Republic of China. (2016). China's Policy Paper on Latin America and the Caribbean. Retrieved from http:// www.gov.cn/english/official/2008-11/05/content_1140347.htm 
Myers, M. \& Gallagher, K. (2018). Chinese Finance to Latin America and the Caribbean in 2017. The Dialogue. Retrieved from https://www. thedialogue.org/resources/chinese-finance-to-latin-america-and-thecaribbean-in-2017/

OPEC.(2016). OPEC share of world crude oil reserves. OPEC Annual Statistical Bulletin 2016. Retrived from http://www.opec.org/opec_web/en/ data_graphs/330.htm

Pavlićević, D., \& Kratz, A. (2017). Testing the China Threat paradigm: China's high-speed railway diplomacy in Southeast Asia. The Pacific Review, 31(2), pp 151-168. doi 10.1080/09512748.2017.1341427

Petras, J. (2014). Latin America and the Paradoxes of Anti-Imperialism and Class Struggle. Retrived from http://petras.lahaine.org/?p=2000

Ray, R., \& Gallagher, K. (2015). China-Latin America Economic Bulletin 2015 Edition. Retrived from http://www.bu.edu/pardeeschool/files/2015/02/ Economic-Bulletin-2015.pdf

Russia Today. (2014). Nicaragua Canal - potential threat to the US and Western powers. Retrived from https://www.rt.com/op-edge/217779-nicaraguawaterway-project-china/

Sanchez, C. (2015). Mexico halts Chinese mega-mall project after damage to environment. Los Angeles Times. Retrived from http://www.latimes. com/world/mexico-americas/la-fg-mexico-closing-chinese-megamall20150128-story.html

Shixue, J. (2019) . U.S. should keep its hands offVenezuela. CGTN. Retrieved from https://www.cgtn.com/search?keyword=U.S.\%20should\%20 keep\%20its\%20hands\%20off\%20Venezuela

Smith, M. (2015). Global economic worries keep crude in check. fuel fix. Retrived from http://fuelfix.com/blog/2015/09/03/global-economicworries-keep-crude-in-check/

Suggett, J. (2010). Latest Venezuela-China Deals: Orinoco Agriculture, Civil Aviation, Steel, and \$5Billion Credit Line. Venezuelanalysis.com. Retrived from http://venezuelanalysis.com/news/5548

Swan, J. , \& Lawler, D. (2018). Bolton to praise Bolsonaro, declare "Troika of Tyranny" in Latin America speech. Retrived from https://www.axios.com/ john-bolton-latin-america-speech-bolsonaro-troika-c7d41d0c-f0c7-4bb9b19a-9ac0b693ca0e.html

Tavener, B. (2011). Brazil Joins CELAC, a Non-US LatAm Bloc. The Rio Times. 
Retrived from http://riotimesonline.com/brazil-news/rio-politics/braziljoins-celac-non-us-bloc/\#

Tegel, S. (2014). Venezuela's Maduro to U.S.: Don't kill me, Give Peace a Chance. NBC News. Retrived from http://www.nbcnews.com/storyline/ venezuela-crisis/venezuelas-maduro-u-s-dont-kill-me-give-peace-chancen56626

The South China Morning Post. (2016, December 31). Venezuela is the most dangerous place for Chinese foreign investment. China's Foreign Trade, 2(39), 30.

Trading economics online data base. (2018). Crude oil price historical. Retrived from http://www.tradingeconomics.com/commodity/crude-oil

U.S. Energy Information Administration. (2015). U.S. Imports by Country of Origin.

Retrived from http://www.eia.gov/dnav/pet/pet_move_impcus_a2_nus_ epc0_im0_mbblpd_a.htm

Wang, K. (2014). A New Chapter in China-LAC Friendship and Cooperation. Retrived from http://bb.china-embassy.org/eng/sgxw/t1179133.htm

Wei, T. (2013). Logistics project of the century. China Daily.

Retrived from http://africa.chinadaily.com.cn/weekly/2013- 07/05/content_16735118.htm

Why China is lending \$ 5 Billion to Struggling Venezuela. (2015). The Economist. Retrived from http://www.economist.com/news/business-andfinance/21663169-cash-be-invested-oil-will-deliver-dubious-benefitsboth-parties-why-china-loaning-5

Wyss, J. (2018). Washington and Cuba butt heads over Venezuela at heated Americas summit. Miami Herald. Retrived from http://www.miamiherald.com/news/nation-world/world/americas/article208920324. $\mathrm{html}$ ?anf=NATION_AND_WORLD

Xi, J. P. (2014). The Governance of China. Beijing: Foreign Languagues Press Co. Ltd.

Xi, J. P. (2014). Build a Communitu of Shared Destiny for Common Progress. Retrived from http://www.gov.cn/xinwen/2014-07/18/content_2719920.htm Xinhua News. (2014). Mexico revoking rail deal due to domestic factors: China. China Daily. Retrived from http://www.chinadaily.com.cn/china/2014-11/09/content_18889036.htm 
Xinhua News. (2015). Chinese company to build Nicaragua Canal as green project. Retrived from http://www.china.org.cn/business/2015-06/23/ content_35893430.htm

Xue, L. (2014). Chinese Diplomatic Risk was reflected from Belt and Road initiative. Financial Times. Retrived from http://www.ftchinese.com/ story/001059886?full=y

Zhao, S. \& Jun, L. (2014). China's 58 partners around the world'. People's Daily. Retrived from http://en.people.cn/n/2014/0728/c98649-8761668.html Zhu, Q. Q. (2016). China-LAC Overall Cooperation Pushes Ahead on a Great Journey. Ministry of Foreign Affairs. Retrived from http://www.chinacelacforum.org/eng/zyxw_1/t1338784.htm 